\title{
Development of an iron-amended biofilter for removal of arsenic from rural Canadian prairie potable water
}

\author{
A. M. Gottinger ${ }^{1,2}$, D. J. Wild ${ }^{1}$, D. McMartin ${ }^{2}$, \\ B. Moldovan ${ }^{3} \&$ D. Wang ${ }^{4}$ \\ ${ }^{1}$ Mainstream Water Solutions Inc., Canada \\ ${ }^{2}$ Faculty of Engineering \& Applied Science, University of Regina, \\ Canada \\ ${ }^{3}$ Cameco Corporation, Canada \\ ${ }^{4}$ Centre for Sustainable Infrastructure Research, \\ National Research Council of Canada, Canada
}

\begin{abstract}
The current study examined the use of a ZVI (zero valent iron)/sand filter for the removal of arsenic (As) from Canadian Prairie ground water sources. Batch isotherm data indicated a favourable reaction represented by the Langmuir isotherm equation with loading capacities of 5000 and $2000 \mathrm{mg} \mathrm{As} / \mathrm{kg}$ ZVI. Column experiments using arsenate-spiked RO water $(50 \mu \mathrm{g} / \mathrm{L})$ and varying volumetric ratios of ZVI to sand indicated no statistical difference in arsenicremoval performance above a ZVI/sand ratio of $20 / 80(\%, v / v)$ with removal efficiencies of greater than $98 \%$. A second column study using two ground water sources with 50/50 and 40/60 ZVI/sand filters achieved $89-96 \%$ As removal.

A pilot study using a 50/50 ZVI/sand filter integrated into the existing smallscale biological system showed arsenic removal efficiency of approximately $99.7 \%$. By incorporating this $\mathrm{ZVI} /$ sand filter into existing biological treatment, it was capable of removing As to concentrations below $0.1 \mu \mathrm{g} / \mathrm{L}$ and reducing the concentrations of other contaminants, such as ammonia, iron and manganese. The overall performance of the pilot system indicates the $\mathrm{ZVI} /$ sand filter is a viable option for arsenic removal from drinking water for small communities (populations $<5000$ ).
\end{abstract}

Keywords: arsenic, ZVI/sand filter, adsorption isotherm, slow sand filtration. 


\section{Introduction}

Arsenic (As) occurs in natural waters and its concentration depends on the local hydrology, geology and geochemical characteristics of the aquifer [1]. The most common As-containing mineral is arsenopyrite, which upon oxidation, releases arsenic into water [2]. Arsenic can exist in four oxidation states $\left(\mathrm{As}^{5+}, \mathrm{As}^{3+}, \mathrm{As}^{0}\right.$, and $\mathrm{As}^{3-}$ ). In most ground waters, arsenic exists primarily as $\mathrm{As}^{3+}$ and $\mathrm{As}^{5+}$ with $\mathrm{As}^{3+}$ being up to 60 times more toxic and generally more mobile and difficult to remove than $\mathrm{As}^{5+}$ [3].

The As concentrations in most Canadian Prairie ground water supplies is typically less than $25 \mu \mathrm{g} / \mathrm{L}$, therefore, there has not been significant concern until the maximum allowable concentration (MAC) for As was reduced from 25 to 10 $\mu \mathrm{g} / \mathrm{L}$ in the new Guidelines for Canadian Drinking Water Quality [4].

Many of the currently available As removal technologies for small to medium-sized water treatment systems require a considerable capital investment. These treatment methods also have associated operating costs such as chemical addition for co-precipitation, replacement of expensive media, or contaminated sludge removal that also requires a skilled operator.

An assessment identified 63 rural, remote and resort communities in the western Canadian provinces that do not meet the new MAC guidelines for As and will require innovative potable water treatment solutions [5]. With the need for treatment identified Mainstream Water Solutions Inc., initiated a project to develop a suitable small-scale As removal technology. The present study consisted of initial research, identification of options, and engineering optimisation to develop a proprietary technology using chemical-free methods of treatment.

Pokhrel et al. [6] evaluated various small water treatment configurations for As removal on Saskatchewan ground water including two slow sand filter (SSF) systems. They found that the SSF systems were highly efficient, at up to $96 \%$ As removal. SSF systems are re-emerging technologies that are particularly well suited to small communities because they are simplistic in operation, require little process adjustment and technical expertise, and are economical to install and operate. Several biological SSF municipal water treatment systems have been recently installed in the Canadian Prairie provinces.

Under conditions of sufficient Fe (soluble including both ferric and ferrous) content, SSFs can effectively remove As from ground water. A ratio of at least 20:1 Fe to As must exist to promote adsorption and co-precipitation with As [7]. Where Fe is lacking, it may be added through media such as ZVI (zero valent iron) filings. ZVI filings are a proven and effective media for As removal in permeable reactive barriers, in ZVI filings columns or in a mixture with filtration sand in columns.

This research was designed to identify and quantify an optimised chemicalfree potable water treatment method using ZVI filings for regulatory As removal from ground water. The specific objectives were: (1) to investigate the use of ZVI filings for As removal, (2) to identify the optimal ratio of ZVI/sand for As removal, (3) to evaluate the designed ZVI filings configuration for As removal 
from the source water of two local communities, (4) to determine the ZVI filing's loading capacity and, (5) to determine the impacts on performance of a scaled-up pilot unit. These objectives were met through batch adsorption experiments, continuous-flow column studies, and a pilot study.

\section{Materials and methods}

\subsection{Water sources}

Raw ground water samples were obtained from the resort villages of Kannata Valley and Buena Vista, SK on Last Mountain Lake, approximately $50 \mathrm{~km}$ northwest of the capital city, Regina. The ground water at each community contains Fe:As ratios between 56:1 and 9:1, respectively (table 1). Each represents a particular challenge to removal of As by conventional filtration methods.

Despite a theoretically adequate Fe:As ratio of 56:1, pilot-scale SSF treatment at Kannata Valley indicated insufficient As removal. In particular, the Kannata Valley water matrix contains interfering ions including high concentrations of sulfate and bicarbonate as well as organic matter. As(III) is the predominant chemical species (30 to $34 \mu \mathrm{g} / \mathrm{L}$ ).

Removal of As from Buena Vista raw water proved difficult during previous SSF pilot-scale tests and was attributed primarily to an insufficient $\mathrm{Fe}$ :As ratio at 9:1. Unlike Kannata Valley, $\mathrm{As}(\mathrm{V})$ is the predominant chemical species (12 to 13 $\mu \mathrm{g} / \mathrm{L})$.

Table 1: $\quad$ Summary of raw water quality for communities of Kannata Valley and Buena Vista, SK.

\begin{tabular}{ccc}
\hline Parameter & Kannata Valley & Buena Vista \\
\hline & \multicolumn{2}{c}{$\mathrm{mg} / \mathrm{L}$} \\
\hline Arsenic & 0.0370 & 0.0170 \\
\hline Iron & 2.09 & 0.160 \\
\hline Manganese & 0.130 & 0.0620 \\
\hline Ammonia-N & 3.37 & 1.03 \\
\hline DOC & 5.00 & 3.00 \\
\hline Total Alkalinity $\left(\right.$ as $\left.\mathrm{CaCO}^{3}\right)$ & 502 & 358 \\
\hline Bicarbonate & 612 & 423 \\
\hline Chloride & 174 & 13.0 \\
\hline Fluoride & 0.200 & 0.400 \\
\hline Calcium & 93.0 & 23.1 \\
\hline Sodium & 531 & 158 \\
\hline Sulfate & 840 & 87.3 \\
\hline Total Hardness $($ as $\mathrm{CaCO}$ & & 100 \\
\hline Turbidity $(\mathrm{NTU})$ & 427 & 0.780 \\
\hline $\mathrm{pH}$ & 16.8 & 7.80 \\
\hline Conductivity $(\mu \mathrm{S} / \mathrm{cm})$ & 7.70 & 880
\end{tabular}




\subsection{Adsorbent media}

ZVI filings were 20-40 mesh (ASTM) aggregate $(0.45-0.55 \mathrm{~mm})$ obtained from Peerless Metals (Detroit, Michigan). BET analysis to determine filings surface area was completed with indeterminable results likely due to pore sizes smaller than $3.5 \AA$. However, research has indicated that $\mathrm{Fe}^{0}$ surface area is not a primary factor controlling As adsorption [8].

\subsection{Experiments}

\subsubsection{Batch experiments}

$10 \mathrm{~g}$ of ZVI filings were added to $100 \mathrm{ml}$ of water containing between $1 \mu \mathrm{g} / \mathrm{L}$ to $1.2 \mathrm{~g} / \mathrm{L} \mathrm{As}(\mathrm{V})$. The solutions were agitated on an orbital table shaker $(100 \mathrm{rpm})$ for $48 \mathrm{~h}$ after which an aliquot was drawn, filtered with a $0.45 \mu \mathrm{m} \mathrm{GF} / \mathrm{C}$ membrane and analysed by GFAAS for residual As concentrations. Adsorption data was fitted to Freundlich and Langmuir isotherms and equation parameters tested for significance at the $95 \%$ confidence interval using the student's t-test.

\subsubsection{Continuous-flow column studies}

There were two phases included in the column studies. Phase I examined the performance of various ratios of ZVI and sand in the columns with RO water, while Phase II determined the performance of columns loaded with two different ratios of $\mathrm{ZVI} /$ sand to remove As from Kannata Valley and Buena Vista ground water.

Column experiments were designed to replicate a full-scale SSF operation. The columns comprised triplicate sets of 2 L HDPE Nalgene carboys with a bottom outlet. Biologically active filtration sand $\left(\mathrm{d}_{10}: 0.45-055 \mathrm{~mm}\right)$ was obtained from an operating SSF. Time series effluent samples were collected from the column outlets, filtered with a $0.45 \mu \mathrm{m} \mathrm{GF} / \mathrm{C}$ membrane, preserved with nitric acid and analysed by ICP-MS. Arsenic speciation tests (ion exchange tube/ICP-MS) were completed on raw, ozonated and treated water.

2.3.2.1 Phase I: RO water RO water spiked with sodium arsenate and a complex nutrient solution was pumped through columns containing 6 ratios of ZVI/biologically-active sand (table 2).

Table 2: $\quad$ Composition of Phase I columns.

\begin{tabular}{|c|c|c|}
\hline Column \# & $\%$ ZVI by volume & $\%$ sand by volume \\
\hline $1-3$ & 0 & 0 \\
\hline $4-6$ & 0 & 100 \\
\hline $7-9$ & 50 & 50 \\
\hline $10-12$ & 40 & 60 \\
\hline $13-15$ & 30 & 70 \\
\hline $16-18$ & 20 & 80 \\
\hline
\end{tabular}

The columns were assembled by adding a base of gravel (effective size, $\mathrm{d}_{10}$ : 3.0-3.5 mm), including both blank and control columns, and then the $\mathrm{ZVI} / \mathrm{sand}$ 
media of various ratios (table 2). The total media volume was $1.17 \times 10^{-2} \mathrm{~m}^{3}$ $\left(0.0414 \mathrm{ft}^{3}\right)$. The columns were constructed in triplicate with each media configuration.

The nutrient solution (containing inorganic nutrients, such as nitrate and phosphate, to maintain biological sand activity in the column) was added to the influent water throughout the duration of the experiment. As(V) was further added to the nutrient-modified RO influent at a concentration of $50 \mu \mathrm{g} / \mathrm{L}$. Influent water was prepared no more than $24 \mathrm{~h}$ prior to beginning the column experiments.

A column rack was built to support 18 columns that were supplied with the modified RO influent water using a submersible pump into a PVC feedline. Kynar needles valves on the influent and effluent lines regulated the flow rate through each column. The columns were operated in downflow mode with a hydraulic loading rate of $0.023 \mathrm{~m} / \mathrm{h}\left(0.01 \mathrm{gpm} / \mathrm{ft}^{2}\right)$.

The columns were allowed to stabilize for 7 days before As-laden water was applied. A time series of effluent samples were collected from each column over the 4-week experimental period.

2.3.2.2 Phase II: Kannata Valley and Buena Vista ground water In Phase II, two separate column apparatuses were built to remove As from ground water samples collected from two rural resort communities near Regina, SK. Again, triplicate columns were investigated at two chosen media ratios effective in Phase I. The ZVI/sand ratios tested were 50/50 and 40/60 and also included triplicate columns at $0 / 100(\mathrm{v} / \mathrm{v})$.

Two $66 \mathrm{~cm}$ HDPE ozone contacting tanks were used in Phase II influent water preparation. According to Mainstream Water Solutions standard design each tank included a sealed lid fitted with a balanced barometer and catalytic ozone destructor. Ozone was supplied by a $4 \mathrm{~g} / \mathrm{h}$ corona discharge generator (air fed) and applied via sidestream injection. The raw water was ozonated until the oxidation-reduction potential (ORP) reached approximately $500 \mathrm{mV}$ at which point $\mathrm{As}(\mathrm{V})$ should be the predominant species present. The feed rate into each column was regulated using kynar needle valves. The columns were acclimatized for 6 days using nutrient-spiked RO water. On day 7, ozonated Kannata Valley and Buena Vista raw water was introduced. The columns were operated in downflow mode with a hydraulic feed rate of $0.023 \mathrm{~m} / \mathrm{h}$.

\subsubsection{Pilot study}

The pilot study was designed to confirm the laboratory results regarding optimal $\mathrm{ZVI} /$ sand media and anticipated As removal efficiency at one community, Kannata Valley. Mainstream Water Solutions BioFiltration Water Treatment System, based on SSF technology, was used. The system included ozone pretreatment, a ZVI/sand filter, a roughing pre-filter, the SSF and biological activated carbon (BAC) filter (table 3 ). Figure 1 provides a process diagram of the system. 
Table 3: $\quad$ Pilot system processes.

\begin{tabular}{|c|c|c|c|c|}
\hline & ZVI/sand & Roughing & SSF & $\mathrm{BAC}$ \\
\hline $\begin{array}{l}\text { Filter } \\
\text { Size }\end{array}$ & $46 \mathrm{~cm} Ø \times 165 \mathrm{~cm}$ & $46 \mathrm{cmØ} \times 165 \mathrm{~cm}$ & $66 \mathrm{cmØ} \mathrm{\times} 165 \mathrm{~cm}$ & $\begin{array}{c}66 \mathrm{~cm} Ø \times 165 \\
\mathrm{~cm}\end{array}$ \\
\hline $\begin{array}{l}\text { Media } \\
\text { (effective } \\
\text { size) }\end{array}$ & $\begin{array}{c}50 / 50, \%(\mathrm{v} / \mathrm{v}) \\
\text { mixture of ZVI } \\
\text { and quartz silica } \\
\text { sand }(20 \times 40 \text { mesh } \\
\text { ASTM } \\
(0.45-0.55 \mathrm{~mm}))\end{array}$ & $\begin{array}{c}\text { Pea gravel } \\
(3.0-3.5 \mathrm{~mm})\end{array}$ & $\begin{array}{l}\text { Quartz silica sand } \\
\text { (20x40 mesh } \\
\text { ASTM } \\
(0.45-0.55 \mathrm{~mm}))\end{array}$ & $\begin{array}{c}\text { Activated } \\
\text { carbon }(10 \times 30 \\
\text { mesh U.S. } \\
(0.6-0.8 \mathrm{~mm}))\end{array}$ \\
\hline $\begin{array}{l}\text { Total } \\
\text { Media } \\
\text { depth }\end{array}$ & $88 \mathrm{~cm}$ & $88 \mathrm{~cm}$ & $88 \mathrm{~cm}$ & $88 \mathrm{~cm}$ \\
\hline $\begin{array}{c}\text { Media } \\
\text { Volume }\end{array}$ & $0.15 \mathrm{~m}^{3}$ & $0.15 \mathrm{~m}^{3}$ & $0.30 \mathrm{~m}^{3}$ & $0.30 \mathrm{~m}^{3}$ \\
\hline $\begin{array}{c}\text { Filter } \\
\text { Surface } \\
\text { Area }\end{array}$ & $0.17 \mathrm{~m}^{2}$ & $0.17 \mathrm{~m}^{2}$ & $0.34 \mathrm{~m}^{2}$ & $0.34 \mathrm{~m}^{2}$ \\
\hline
\end{tabular}

The ozone contacting system was configured to deliver a maximum ozone dose of $8 \mathrm{~g} / \mathrm{h}$ to facilitate the oxidation of $\mathrm{As}(\mathrm{III})$ to $\mathrm{As}(\mathrm{V})$. Ozonation also oxidized other metals in the raw ground water including manganese and iron into forms that precipitate in the roughing and SSFs. Furthermore, ozone addition increases the oxidation of ZVI filings leading to rust formation, which supports As removal.

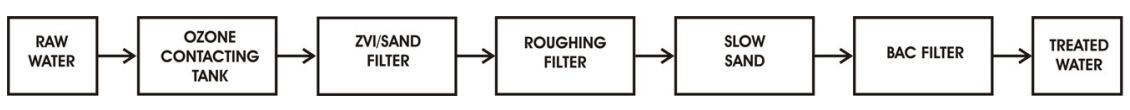

Figure 1: $\quad$ Pilot system processes.

The pilot project included 2 experimental trials - one with a routine flow rate of $1.26 \mathrm{~L} / \mathrm{min}$ and an ozone dose of $105 \mathrm{mg} / \mathrm{L}$. The second experiment was set up with the same flow rate $(1.26 \mathrm{~L} / \mathrm{min}$; however without the addition of ozone (pre-oxidation).

\section{Results}

\subsection{Batch study}

Batch study data was fitted to both Freundlich and Langmuir adsorption isotherms and both were statistically significant at the $95 \%$ confidence interval. However the Langmuir isotherm more adequately describes As adsorption onto ZVI in both authentic ground water samples. The Langmuir isotherm curve for Kannata Valley is shown in figure 2. These results are similar to published literature where adsorption of As onto various adsorbents followed the Langmuir isotherm [9]. 


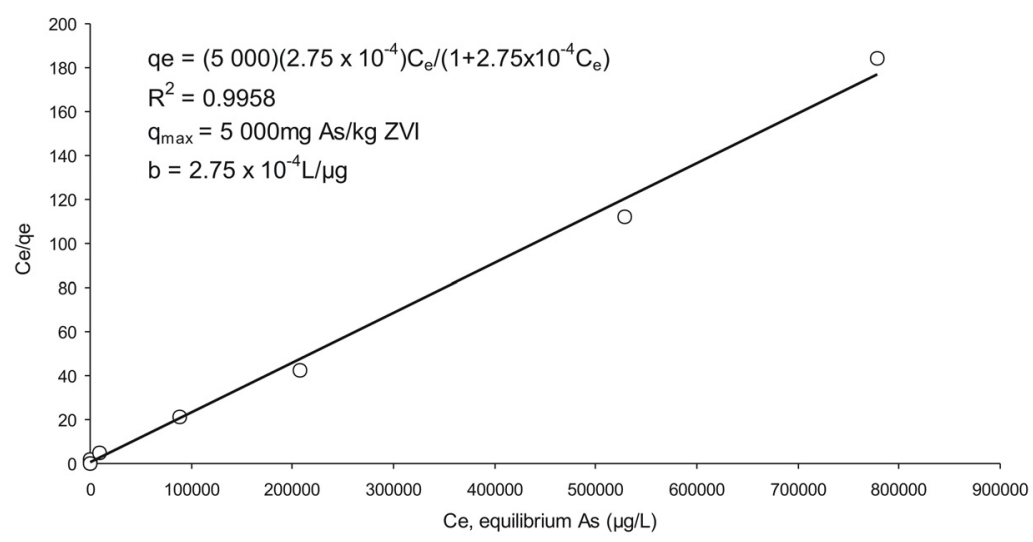

Figure 2: Langmuir adsorption isotherm for Kannata Valley ground water.

Average As removal efficiencies for Kannata Valley and Buena Vista raw water were 97 and $95 \%$, respectively, for the selected range of As concentrations. As removal was greater than $90 \%$ in all samples up to a spiked concentration of $200,000 \mu \mathrm{g} / \mathrm{L}$. A comparable binding energy constant (b) was observed for both waters suggesting similar adsorbate-adsorbent interactions. The maximum adsorption capacity, determined by the Langmuir $\mathrm{q}_{\max }$ constant, was 5000 and $2000 \mathrm{mg} \mathrm{As} / \mathrm{kg}$ ZVI for Kannata Valley and Buena Vista respectively and are consistent with earlier reported As removal capacities of ZVI filings [8, 10-12].

\subsection{Continuous-flow column studies}

\subsubsection{Phase I: RO water}

Nutrient-modified RO water spiked to $50 \mu \mathrm{g} / \mathrm{L} \mathrm{As}(\mathrm{V})$ was pumped through triplicate columns containing five different ratios of $\mathrm{ZVI} / \mathrm{sand}(\mathrm{v} / \mathrm{v})$ ranging from $0 / 100$ to $50 / 50$ (Table 4). Each set of columns was examined for performance at similar loading rates. The columns were operated at $4 \mathrm{~mL} / \mathrm{min}(0.023 \mathrm{~m} / \mathrm{h})$ for sufficient duration to achieve 149 bed volumes (total throughput volume of $173 \mathrm{~L})$.

The $0 / 100$ columns containing sand only provided minimal As removal as anticipated. All ZVI/sand columns, except those at $20 / 80$ achieved $>98 \%$ removal of influent As where the As was reduced from 50 to $<1 \mu \mathrm{g} / \mathrm{L}$ (table 4).

A Tukey multiple comparison test was completed on the performance data. Analysis at the $95 \%$ confidence interval indicates that the As removal performance of the $20 / 80$ columns was statistically poorer than the other $\mathrm{ZVI} /$ sand columns. The remaining columns performed statistically similarly to each other. Although the 20/80 columns were capable of removing As to below $10 \mu \mathrm{g} / \mathrm{L}$, they did not achieve the same level of performance as the remaining columns. The reduced ZVI volume in the 20/80 columns may have resulted in dissolved As passing through the column via "null" paths without reacting with the ZVI or oxidized Fe [11]. 
Table 4: $\quad$ Summary of results from nutrient-enhanced RO water experiment.

\begin{tabular}{cccc}
\hline $\begin{array}{c}\text { ZVI/ } \\
\text { Sand } \\
(\mathrm{v} / \mathrm{v})\end{array}$ & $\begin{array}{c}\text { Initial As } \\
(\text { Ave. } \pm \text { St. Dev. }) \\
(\mu \mathrm{g} / \mathrm{L})\end{array}$ & $\begin{array}{c}\text { Final As } \\
(\text { Ave. } \pm \text { St. Dev. }) \\
(\mu \mathrm{g} / \mathrm{L})\end{array}$ & $\begin{array}{c}\text { \% As Removed } \\
(\text { Ave. } \pm \text { St. Dev. })\end{array}$ \\
\hline $0 / 100$ & $41.70 \pm 0.53$ & $39.42 \pm 2.50$ & $5.42 \pm 16.51$ \\
\hline $50 / 50$ & $41.70 \pm 0.53$ & $0.64 \pm 0.03$ & $98.46 \pm 0.17$ \\
\hline $40 / 60$ & $41.70 \pm 0.53$ & $0.80 \pm 0.08$ & $98.09 \pm 0.46$ \\
\hline $30 / 70$ & $41.70 \pm 0.53$ & $0.56 \pm 0.01$ & $98.67 \pm 0.07$ \\
\hline $20 / 80$ & $41.70 \pm 0.53$ & $1.29 \pm 0.10$ & $92.80 \pm 0.02$ \\
\hline
\end{tabular}

Operationally, variations in hydraulic resistance and, therefore, flow rate were noted, which were due primarily to plugging of pore spaces by the formation of Fe oxides where greater oxygen concentrations existed at the filter inlet [13].

\subsubsection{Phase II: Kannata Valley and Buena Vista ground water}

Triplicate 0/100, 40/60 and 50/50 (v/v) columns were assembled and operated at $0.023 \mathrm{~m} / \mathrm{h}$ for 154 bed volumes $(184 \mathrm{~L})$ without achieving breakthrough. The results for this filtration run are summarized in table 5 .

Table 5: Continuous-flow column performance on authentic ground water.

\begin{tabular}{cccccc}
\hline & $\begin{array}{c}\text { Influent As } \\
(\text { Ave. } \pm \text { St. } \\
\text { Dev. }) \\
(\mu \mathrm{g} / \mathrm{L})\end{array}$ & $\begin{array}{c}\text { Effluent As } \\
(\text { Ave. } \pm \text { St. } \\
\text { Dev. } \\
(\mu \mathrm{g} / \mathrm{L})\end{array}$ & $\begin{array}{c}\text { \% As } \\
\text { Removed } \\
\text { (Ave. } \pm \text { St. } \\
\text { Dev. })\end{array}$ & $\begin{array}{c}\text { Influent Fe } \\
(\text { Ave. } \pm \text { St. } \\
\text { Kev. }) \\
(\mathrm{mg} / \mathrm{L})\end{array}$ & $\begin{array}{c}\text { Effluent Fe } \\
\left(\begin{array}{c}\text { Ave. } \pm \text { St. } \\
\text { Dev. } \\
(\mathrm{mg} / \mathrm{L}\end{array}\right.\end{array}$ \\
\hline \multicolumn{7}{c}{$25.50 \pm 12.33$} \\
\hline $0 / 100$ & $23.80 \pm 5.11$ & $7.52 \pm 443.14$ & $0.10 \pm 0.06$ & $0.06 \pm<0.01$ \\
\hline $50 / 50$ & $23.80 \pm 5.11$ & $2.48 \pm 0.05$ & $89.51 \pm 1.07$ & $0.10 \pm 0.06$ & $0.03 \pm<0.01$ \\
\hline $40 / 60$ & $23.80 \pm 5.11$ & $2.49 \pm 0.34$ & $89.43 \pm 1.64$ & $0.10 \pm 0.06$ & $0.02 \pm<0.01$ \\
\hline \multicolumn{7}{c}{ Buena Vista } \\
\hline $0 / 100$ & $16.44 \pm 0.31$ & $16.43 \pm 1.66$ & $0.72 \pm 93.35$ & $0.37 \pm 0.48$ & $0.04 \pm<0.01$ \\
\hline $50 / 50$ & $16.44 \pm 0.31$ & $0.50 \pm<0.01$ & $96.96 \pm 0.01$ & $0.37 \pm 0.48$ & $0.03 \pm<0.01$ \\
\hline $40 / 60$ & $16.44 \pm 0.31$ & $0.52 \pm<0.01$ & $96.86 \pm 0.13$ & $0.37 \pm 0.48$ & $0.03 \pm<0.01$ \\
\hline
\end{tabular}

The $0 / 100$ control columns were not capable of removing As to below the pending $10 \mu \mathrm{g} / \mathrm{L}$ regulatory standard. In fact, these columns appear to have caused As concentration variation during the treatment.

Both the 50/50 and the 40/60 ZVI/sand column effluent water consistently contained As concentrations below $3 \mu \mathrm{g} / \mathrm{L}$, which equates to $>89 \%$ removal for Kannata Valley ground water. Both sets of ZVI/sand columns achieved As removal efficiency $>96 \%$ thereby resulting in As at less than $0.5 \mu \mathrm{g} / \mathrm{L}$ in the Buena Vista water. Statistically, there was no significant difference in performance between the $50 / 50$ and $40 / 60$ columns within the $95 \%$ confidence interval. 
The higher As removal rate observed in the columns treating Buena Vista ground water was attributed primarily to the greater concentration of As(V) species rather than the more soluble As(III) species, as well as to reduced competitive ions in the water matrix relative to Kannata Valley raw water. Although oxidation promoted the presence of $\mathrm{As}(\mathrm{V})$ in the Kannata Valley water, approximately half of the influent As was As(III). Comparatively, the majority of As in the Buena Vista raw water was As(V). Arsenate (As(V)) reacts more quickly with Fe oxides than As(III) due to the easy formation of ferric arsenate [14, 15]. Additionally, the slow filtration rate may have allowed scale formation of bicarbonate compounds on the ZVI filings limiting the corrosion required for As removal [16, 17]. Some sorption sites may also have been blocked due to particle deposition, which was more prevalent in the relatively complex Kannata Valley water matrix.

As speciation of Kannata Valley water indicated that excessive ozone application ( $>33 \mathrm{mg} \mathrm{O} / \mathrm{L}$ ) was capable of oxidizing only 40 to $60 \%$ of the $\mathrm{As}(\mathrm{III})$ to $\mathrm{As}(\mathrm{V})$. Speciation results on effluent samples also indicated that approximately $50 \%$ of the effluent As was in the As(III) form.

Despite some limitations to As removal from the Kannata Valley ground water, it was clearly noted that both the 40/60 and 50/50 ZVI/sand columns were proficient at removing both $\mathrm{As}(\mathrm{III})$ and $\mathrm{As}(\mathrm{V})$. The ability of ZVI to remove both species has been noted in previously published research [18] in which it was observed that $\mathrm{As}(\mathrm{III})$ was partially oxidized to $\mathrm{As}(\mathrm{V})$ by $\mathrm{Fe}$ corrosion byproducts.

Column effluent was also analysed for effluent Fe concentration to evaluate potential sloughing into the produced water. The results indicate that overall Fe concentrations were lower in the effluent than in the raw water (table 5).

\subsection{Pilot study}

The pilot treatment system was designed with a 50/50 ZVI/sand filter and incorporated pre-ozonation to achieve oxidation of $\mathrm{As}$ (III) from an initial proportion of $57-78 \%$ of total As to $16-21 \%$ of total As in the influent raw water. The experimental results with Kannata Valley ground water are displayed in table 6.

The ZVI/sand filter and SSF were successful in removing the majority of the As in the influent raw water. Total As in the effluent from the ZVI/sand filter was consistently $<0.10 \mu \mathrm{g} / \mathrm{L}$. The effluent from the SSF contained slightly higher

Table 6: As and Fe concentrations in raw water and after pilot system processes.

\begin{tabular}{ccc}
\hline Process & $\begin{array}{c}\text { As conc. } \\
(\text { Ave. } \pm \text { St, Dev }) \\
(\mu \mathrm{g} / \mathrm{L})\end{array}$ & $\begin{array}{c}\text { Fe conc. } \\
(\text { Ave. } \pm \text { St, Dev }) \\
(\mathrm{mg} / \mathrm{L})\end{array}$ \\
\hline Raw & $30.76 \pm 22.43$ & $0.79 \pm 0.54$ \\
\hline ZVI/sand & $<0.10 \pm<0.01$ & $<0.09 \pm<0.01$ \\
\hline SSF & $2.04 \pm 1.15$ & $0.03 \pm<0.01$ \\
\hline BAC & $1.68 \pm 0.85$ & $<0.09 \pm<0.01$ \\
\hline
\end{tabular}


As concentration attributed to limited precipitation of complexed $\mathrm{Fe}$ and $\mathrm{As}$ in that filter. Regardless, As in the treated water from the Mainstream system never exceeded 3.9 $\mu \mathrm{g} / \mathrm{L}$, far below the new MAC. In addition, several samples were analysed for total dissolved Fe content throughout the pilot process to examine potential Fe leaching from the $\mathrm{ZVI} /$ sand filter. Results indicated total $\mathrm{Fe}$ concentrations below the detectable limit. From this analysis it appears that the $\mathrm{ZVI} /$ sand filter also removed Fe from the raw water and did not allow leaching (table 6). Complete analysis of system effluent proved overall good quality potable water production. iron and manganese were removed to well below the target objectives of $0.3 \mathrm{mg} / \mathrm{L}, 0.05 \mathrm{mg} / \mathrm{L}$ respectively. Ammonia was reduced to $<0.25 \mathrm{mg} / \mathrm{L}$ and turbidity was consistently well below 1 NTU.

\subsubsection{No oxidation of As(III)}

The pilot system was operated for 7 days without ozone oxidation at a constant flow rate of $1.26 \mathrm{~L} / \mathrm{min}$. Although there was no oxidation of As species removal was still successful. The ZVI/sand filter effectively removed As(III) and As(V); and total As in the treated water never exceeded $1 \mu \mathrm{g} / \mathrm{L}$. The average removal of As(III) was $97 \%$ and As(V) was 99\%. It was deemed likely that the slower SSF filtration rates allowed for adequate contact time and removal of As(III).

\subsubsection{Filter operation}

The top $3 \mathrm{~cm}$ of the filter bed, where DO and oxidation of ZVI were high, became cemented over time due to formation of Fe oxides. In order to restore flow a daily water scour was required. Others recommend using the lowest effective Fe:sand ratio to avoid excessive Fe hydroxide formation clogging [16]. Because the 30/70 ZVI/sand media was shown to be effective for As removal and limits the Fe:sand ratio, this was deemed the optimal media configuration for both operational and regulatory reasons.

A study of a pilot-scale filter using 30/70 ZVI/sand was completed over a short duration (14 days) to prove this conclusion. Not only does the $30 / 70$ media mixture require less maintenance, it performed similarly to the 50/50 media mixture regarding As removal efficiency.

\section{Economic feasibility}

Based on the loading capacity observed in the batch isotherm study and assuming that only $25 \%$ of the Fe is available for adsorption [16], the life of the media in (6) ZVI/sand filters (based on a conceptual full-scale plant design for Kannata Valley at $720 \mathrm{~m}^{3}$ ) is estimated to be approximately 40 months. The treatment cost is estimated to be $<\$ 0.01 / \mathrm{L}$ and includes filter installation, media, operation and maintenance, and disposal costs.

A comparison of adsorptive media reveals that $\mathrm{ZVI} /$ sand is economical with respect to media and treatment cost and has a satisfactory estimated life (table 7). ZVI filings can be obtained for less than $\$ 1.50 / \mathrm{kg}$ and the cost of manufacturing this filter is comparable to a BAC filter making it a feasible technology for Mainstream Water Solutions to utilize. 
Table 7: $\quad$ Treatment costs and media replacement frequency for comparable adsorptive media.

\begin{tabular}{|c|c|c|c|c|c|}
\hline Media & $\begin{array}{c}\text { BV } \\
\text { Treated }\end{array}$ & $\begin{array}{l}\text { Media density } \\
\qquad\left(\mathrm{kg} / \mathrm{m}^{3}\right)\end{array}$ & $\begin{array}{l}\text { Media cost } \\
\qquad\left(\mathrm{m}^{3}\right)\end{array}$ & $\begin{array}{l}\text { Treatment cost } \\
(\$ / L)\end{array}$ & $\begin{array}{l}\text { Change-out } \\
\text { frequency } \\
\text { (months) }\end{array}$ \\
\hline $\mathrm{E}^{2} 3^{\mathrm{a}}$ & 54700 & 454 & 5377 & 0.10 & 28.6 \\
\hline $\mathrm{GFH}^{\mathrm{a}}$ & 18300 & 1281 & 7769 & 0.42 & 9.6 \\
\hline $\mathrm{Z33}^{\mathrm{a}}$ & 3300 & 881 & 486 & 0.15 & 1.7 \\
\hline $\mathrm{ZVI} /$ sand $^{\mathrm{b}}$ & 25900 & 1929 & 1305 & $<0.01$ & 40 \\
\hline
\end{tabular}

\section{Conclusions}

The present study concluded that ZVI/sand filtration is an effective adsorbent for As removal in potable water treatment. Column and pilot studies proved that a balance of sufficient ZVI content for both As removal and for low maintenance requirements can be achieved in the range of 30/70 ZVI/sand for the raw water sources investigated. The results also showed that ZVI can remove both As species to well below $4 \mu \mathrm{g} / \mathrm{L}$ without significant Fe leaching. While the use of a $\mathrm{ZVI} /$ sand filter for arsenic removal is an economically feasible treatment in comparison to alternative technologies, disposal of spent media as well as treatment of backwash waste prior to release must be considered.

\section{References}

[1] Bhattacharya, P., Ahmed, K., Hasan, M., Broms, S., Fogelstrom, J., Jacks, G., Sracek, O., von Bromssen, M. \& Routh, J., Mobility of arsenic in groundwater in part of Brahmanbaria district, NE Bangladesh. Managing Arsenic in the Environment from Soil to Human Health, eds. R. Naidu, E. Smith, G. Owens, P. Bhattacharya and P. Nadebaum, CSIRO Publishing, pp. 95-116, 2006.

[2] Bhumbla, D. \& Keefer, R., Arsenic mobilization and bioavailability in soils. Arsenic in the Environment, Part I: Cycling and Characterization, ed. J. Nriagu, John Wiley and Sons, Inc. pp. 51-82, 1994.

[3] Korte, N.C. \& Fernando, Q., A review of As(III) in groundwater. Critical Reviews in Environmental Controls, 21, pp. 1-39, 1991.

[4] Guidelines for Canadian Drinking Water Quality. Health Canada, 2008. www.hc-sc.gc.ca/ewh-semt/alt_formats/hecs-sesc/pdf/pubs/watereau/sum_guide-res_recom/summary-sommaire-eng.pdf

[5] Thomas, V., Market Assessment - Arsenic Removal Technology for Drinking Water. Unpublished report, 2007.

[6] Pokhrel, D., Viraraghavan, T. \& Braul. L., Evaluation of treatment systems for the removal of arsenic from groundwater. Practice Periodical of 
Hazardous, Toxic and Radioactive Waste Management, 9(3), pp.152-157, 2005.

[7] Treatment Technologies for Arsenic Removal. U.S. Environmental Protection Agency, National Risk Management Research Laboratory, EPA/600/S-05/006 Online: www.epa.gov/nrmrl/pubs/600s05006/600s 05006.pdf

[8] $\mathrm{Su}$, C. \& Puls, R., Arsenate and arsenite removal by zerovalent iron: kinetics, redox transformation, and implications for in situ groundwater remediation. Environmental Science and Technology, 35(7). pp. 1487-1492, 2001.

[9] Guo, H., Stuben, D. \& Berner, Z., Removal of arsenic from aqueous solution by natural siderite and hematite. Applied Geochemistry, 22(5), pp. 1039-1051, 2007.

[10] Nikolaidis, N., Dobbs, G. \& Lackovic, J., Arsenic removal by zero-valent iron: field, laboratory and modeling studies. Water Research, 37(6), pp.1417-1425, 2003.

[11] Lien, H. \& Wilkin, R., High-level arsenic removal from groundwater using zero-valent iron. Chemosphere, 59(3), pp.377-386, 2004.

[12] Lackovic, J., Nikolaidis, N. \& Dobbs, G., Inorganic arsenic removal by zero-valent iron. Environmental Engineering Science, 17(1), pp. 29-39, 2000.

[13] Johnson, R., Tratnyek, P. Miehr, R, Thoms, R. \& Bandstra, J., Reaction of hydraulic conductivity and reactivity in zero-valent iron columns by oxygen and TNT. Ground Water Monitoring \& Remediation, 25(1), pp.129-136, 2005.

[14] Joshi, A. \& Chaudhuri, M., Removal of Arsenic from Ground Water by Iron Oxide-Coated Sand. Journal of Environmental Engineering, 122(8), pp. 769-771, 1996.

[15] Raven, K., Jain, A. \& Loeppert, R., Arsenite and arsenate adsorption on ferrihydrite: kinetics, equilibrium, and adsorption envelopes. Journal of Environmental Science and Technology, 32(3), pp. 344-349, 1998.

[16] Leupin, O. \& Hug, S., Oxidation and removal of arsenic(III) from aerated groundwater by filtration through sand and zero-valent iron. Water Research, 39(9), pp.1729-1740, 2005.

[17] Leupin, O., Hug, S. \& Badruzzaman, A., Arsenic removal from Bangladesh tube well water with filter columns containing zerovalent iron filings and sand. Environmental Science and Technology, 29(20), pp. 8032-8037, 2005.

[18] Su, C. \& Puls, R., Significance of Iron II, III) hydroxycarbonate green rust in arsenic remediation using zerovalent iron in laboratory column tests. Environmental Science and Technology, 38(19), pp. 5224-5231, 2004.

[19] Westerhoff, P., DeHaan, M., Martindale, A. \& Badruzzaman, M., Arsenic Adsorptive Media Technology Selection Strategies. Water Quality Research Journal of Canada, 41(2), pp.171-184, 2006. 